\title{
Consensus
}

Volume 27

Issue 2 In Honour of the Women of the ELCIC

Article 14

$11-1-2001$

\section{A dictionary of early Christian beliefs: a reference guide to more than 700 topics discussed by the early church fathers}

Andrei S. P. Brennan

Follow this and additional works at: http://scholars.wlu.ca/consensus

Part of the Practical Theology Commons

\section{Recommended Citation}

Brennan, Andrei S. P. (2001) "A dictionary of early Christian beliefs: a reference guide to more than 700 topics discussed by the early church fathers," Consensus: Vol. 27 : Iss. 2 , Article 14.

Available at: http://scholars.wlu.ca/consensus/vol27/iss2/14

This Book Reviews is brought to you for free and open access by Scholars Commons @ Laurier. It has been accepted for inclusion in Consensus by an authorized editor of Scholars Commons @ Laurier. For more information, please contact scholarscommons@wlu.ca. 
theologies in unresolved conflict, using the same liturgical expression" (130). With this in mind, he says, the shift to seeing Eucharist at the normal Sunday liturgy demonstrates a slide towards the high-church position. It is this theology which is embraced by practically all Canadian Anglicans today, however they many choose to massage the ordo of the $B C P$ to reflect their own personal taste. Blott concludes by reflecting on the conservative and evolutionary nature of liturgical change. It is impossible, he says, to codify or nail down liturgy for all times and places, as some Anglicans tried to do in the sixteenth and seventeenth centuries.

In these post-Vatican II days of liturgical renewal, it is hard to imagine that these were the raging issues of another time. But they were for Anglicans in Canada, as they were for Lutherans in North America. Some of us can remember, the same debate over offertory and sacrifice raging in the days of the Inter Lutheran Commission on Worship which preceded the 1977 Lutheran Book of Worship! There is a tantalizing reference (131) to the "Muhlenberg Memorial" in the American Protestant Episcopal Church" and its influence on Canadian Anglican liturgical revision. Lutherans who think of the Anglican liturgical tradition as an unchanging monolith will find this book interesting reading. One might look for the similarities and the differences between Lutherans and Anglicans and discover yet more ground we share in common!

Don Neville

Highland Lutheran Church

Calgary, Alberta

\section{A Dictionary of Early Christian Beliefs: A Reference Guide to More Than 700 Topics Discussed by the Early Church} Fathers

David W. Bercot, Editor

Peabody, MA: Hendrickson, 1998

704 pages, \$44.97 Hardcover

In recent years, the ante-Nicene Fathers, sometimes called the "early Christian writers," have enjoyed a renaissance of sorts in terms of 
popularity in theological and pastoral circles. This reference work, prepared by the American "continuing" Anglican cleric and lawyer, David Bercot, is clearly meant to be a companion volume to the reprinted series of Roberts' and Donaldson's classic Ante-Nicene Fathers (1885$1887 \mathrm{CE}$ ), published in ten volumes by Hendrickson in 1994.

The book is prepared in the traditional "encyclopedic dictionary" format. Bercot opens with a chapter on "How to Use this Dictionary" that provides a very brief historical introduction to the source material, and details the limits of the book. Bercot chooses to reference only those works included in the Roberts and Donaldson series that are clearly ante-Nicene (i.e., prior to the first Council of Nicea in $325 \mathrm{CE}$ ) in terms of authorship and dating, with the curious exception of the Apostolic Constitutions, which is dated by most scholars as having been compiled circa $390 \mathrm{CE}$. Bercot explains this inclusion on the notunjustifiable basis that much of the material in the Apostolic Constitutions is in fact ante-Nicene in origin; he excludes materials from the Constitutions that are clearly post-Nicene, or at least notes that they are post-Nicene in the text.

Bercot then continues with a section entitled "Who's Who in the Ante-Nicene Fathers" listing brief biographical statements (with handy pronunciation keys) for many of the significant authors and names encountered in the ante-Nicene material. This short chapter is immediately followed by the alphabetical listing of subjects with entries on biblical persons, books, and events; theological topics, heresies and heresiarchs, moral issues, etc. Many of the entries are prefaced with relevant scriptural quotes, followed by quotations from various Fathers on the topic at hand. Occasionally Bercot inserts an editorial comment for clarification, but most entries consist of several direct quotes from the Fathers in translation.

The layout of the dictionary is very user-friendly. One can seek out topics with relative ease, and find useful patristical quotes that are appropriately referenced (author, approximate date, whether the author was "Eastern" or "Western," volume and page numbers from the AnteNicene Father's series). In many ways it would be an excellent introductory volume to someone unfamiliar with the early Christian writers, as it makes the thoughts of the Fathers accessible on topical issues without a large investigation required on the part of the reader. The dictionary would make an excellent resource for a pastor to improve 
his or her preaching and teaching ministry, making it convenient and easily possible to quote one or more Fathers on a relevant subject in a homily, adult study group, or confirmation class. The dictionary would be useful as a secondary resource for seminary students, as it provides numerous readily available quotes and explanations on subjects crossing a multitude of theological sub-fields. The interested lay Christian wishing to learn more about the writings of the early Christian thinkers (which very much influenced the later Reformers in the West) would find this volume an excellent addition to their home library.

The weaknesses of the volume result largely from two areas: it is a very ambitious project to index a huge corpus of ancient material, and the choice of translations selected by Bercot is dated. As an ambitious work, it was necessary for Bercot to include only a limited number of quotations on each subject. A definite conservative bias can be sensed in terms of which quotations were selected; one might recall that Bercot is well-known in some circles for his earlier book, Will the Real Heretics Please Stand Up?, a polemic against evangelical Protestantism favouring a conservative Anglo-Catholic interpretation of church history and theology. Roberts' and Donaldson's series remains a classic, but the interpretive methodology used in the late nineteenth century leaves much to be desired by modern patristical scholarly norms. Perhaps the most serious problem is the style of language used: the dense, quasi-Elizabethan English favoured by Oxbridge scholars in the Victorian era can be difficult to understand for some, or sadly make a lively church father sound rather dry and snobbish to post-modern North American ears. Another concern might be that one would need to own the (expensive) reprinted series in order to gain the fullest possible value from the dictionary. Still, the dictionary stands well on its own, considering its limitations, and the Ante-Nicene Father's series is available in many libraries and on-line on the World Wide Web.

Despite these limitations, the dictionary provides an excellent resource that allows the early Christian writers to speak directly to us in answering perennial questions for the faithful.

\author{
Andrei S.P. Brennan \\ McMaster University \\ Hamilton, Ontario
}

